\title{
C++ DEMYSTIFIED: A SELF-TEACHING GUIDE
}

\author{
Milan KLEMENT - Jan LAVRINČÍK
}

\section{C++ BEZ PŘEDCHOZÍCH ZNALOSTÍ}

\begin{abstract}
(KENT, J. C++ bez předchozich znalostí. 1. vyd. Brno : Computer Press, 2009. 254 s. ISBN 978-80-
\end{abstract} 251-2411-6.)

Rok 2009 je bohatý na literaturu z oblasti programování. Do našich knihoven si hledá místo nová kniha, která by se mohla stát nepostradatelnou pomůckou učitele střední nebo vysoké školy.

Jeff Kent patř́ mezi uznávané programátory v jazyku C++. Je docentem výpočetní techniky na vyšší střední škole Los Angeles Valley College, kde mimojiné vyučuje i paradigmata dalších programovacích jazyků. Z dalších publikací z pera Jeffa Kenta můžeme jmenovat Visual C\# 2005 bez předchozích znalostí, která taktéž vyšla v nakladatelství Comuter Press.

Kniha má črtnáct kapitol, což je optimální počet z hlediska zařazení do výuky na vysokých školách, protože standardní délka semestru je 14 výukových týdnů.

V první kapitole se autor snaží čtenářům přiblížit, jak funguje

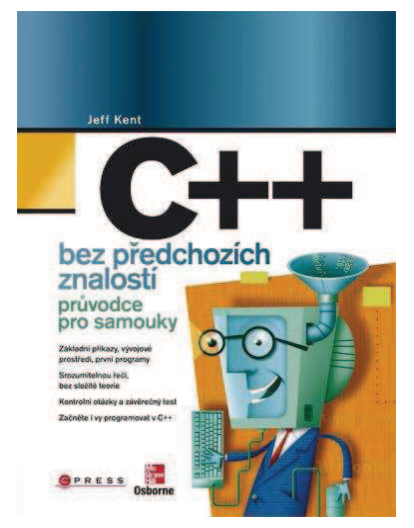
program napsaný $\mathrm{v} \mathrm{C}++$, co je to počítačový program, anatomie programu $\mathrm{v} \mathrm{C}++$, príklad zdrojového kódu a integraci vývojového prostředí. Druhá kapitola je věnovaná paměti a datovým typům. Třetí kapitola nás přivádí k proměnným, deklarování proměnných, přiřazování hodnot. Náplň páté kapitoly je rozhodování, př́kazy if a switch, z objektového programování známé pod termínem podmínky. Vnořené podmínky a logické operátory provází čtenáře šestou kapitolou. Překvapivě celou sedmou kapitolu věnoval autor cyklům typu for. Na cykly řízené podmínkou si musíme počkat až do osmé kapitoly. Pro čtenáře jedno $\mathrm{z}$ obtížnějších témat nalistujeme $\mathrm{v}$ kapitole věnované funkcím. Desátá kapitola věnovaná nastvením, deklaraci, inicializaci, sledování parametru polí je bezpochyby jednou z důležitějších zhlediska vývoje aplikací. Kapitoly jedenáct až čtrnáct jsou charakteristické pouze pro jazyk $\mathrm{C}++$. Kapitola jedenáct nám definuje ukazatele $\mathrm{z}$ úhlu proměnných a konstant, dynamické alokace paměti nebo ukazatelovou aritmetiku. Na céčkové řetězce a trrídy string narazíme $\mathrm{v}$ kapitole dvanáct. Jaké procesy probíhají při otevírání souborů pro čtení nebo pro zápis, uzavírání souborů, nám autor nechal odpověd' až skoro na samotný závěr publikace. V kapitole čtrnáct najdeme mimo struktur a tříd i zamyšlení nad objektově orientovaným programováním z pohledu $\mathrm{C}++$. Celá kniha je zakončena testem na ověření znalostí získaných studiem knihy. K dispozici je i klíč správných řešení.

Celý text knihy je vhodně prokládán krátkými zdrojovými kódy, přičemž autor ctí zásady názornosti a přiměřenosti. Zdrojové kódy rozeznáme podle jiného typu písma (Courier New), který je pro programovací jazyky typický. Pro úplnost mohl autor dodlnit podrobnými popisky funkce každého řádku zdrojového kódu. Nebylo by na škodu ani srovnání zdrojových kódů s jinými jazyky pro názornost (např. Visual Basic, Java, Asembler, Delphi).

Kniha upoutá komickou kresbou na přebalu knihy. Životnosti knihy př́liš nedodává měkký přebal, který však vzhledem k počtu stran nebude tolik namáhaný, nehrozí rozlepení hřbetu a samovolné vypadávání stran.

Knihu bychom mohli doporučit všem zájemcům o techniky programování $\mathrm{v} \mathrm{C}++$, ale díky jednoduchosti textu, kontrolních otázek a závěrečnému testu i pro výukové účely na středních a vysokých škol orientující se na výuku základů programování a algoritmizace.
PhDr. Milan Klement, Ph.D.
Mgr. Jan Lavrinčík, DiS.
Katedra technické a informační výchovy
Pedagogická fakulta UP
Žižkovo nám. č. 5, 771 40, Olomouc, ČR
Tel.: +420 585635811
E-mail: milan.klement@upol.cz
E-mail: nobilis.felis@seznam.cz
Www pracoviště: www.kteiv.upol.cz 